\title{
Fiqh Mu'ämalah Content In Friday Sermon: Dialectics of the Mosque as a Ritual Space and the Market as Economic Space
}

\author{
Musahadi \\ Fakultas Ekonomi dan Bisnis Islam, Universitas Islam Negeri Walisongo \\ Semarang - Indonesia \\ musahadi@walisongo.ac.id
}

\begin{abstract}
This paper describes fiqh mu'āmalah content in Friday sermons at the Great Mosque of Kauman Semarang to understand the dialectics between the mosque as a ritual space and the market as an economic space. This paper's data are in the form of 51 sermons delivered in 2015 from January 1 to December 31, 2015, and interviews with the foundation, ta'mir, and the preachers. This paper shows that Friday sermons' characteristics at the mosque are reflected in their preachers' diversity, both in terms of educational background, scientific fields, organizational affiliations, and professions. This paper finds that fiqh mu'ämalah's content has not become the point of attention of the preachers. This finding is proven by the absence of a sermon theme on fiqh mu'ämalah (mu'āmalah madiyah). The topic that appeared in Friday's sermon was related to Islamic economics's ethical principles and business-related to mu'ämalah adabiyah. The minimal content of fiqh mu'ämalah or economic fiqh in the Friday sermon of the mosque reflects the low intensity of the mosque's dialectics as a ritual space with the market as an economic space. The Friday sermon at this mosque still does not pay more attention to the jamä'ah of Johar market seller as the essential segment.
\end{abstract}

Keyword: fiqh mu'ämalah; Friday sermon; ritual space; economic space

\section{[]}

Tulisan ini mendeskripsikan konten fiqh mu'āmalah dalam khutbah Jum`at di Masjid Agung Kauman Semarang dalam rangka memahami hubungan antara masjid sebagai ritual space dan pasar sebagai economic space. Data tulisan ini berupa 51 khutbah yang disampaikan pada tahun 2015 terhitung mulai 1 Januari sampai dengan 31 Desember 2015 dan wawancara dengan pihak yayasan, ta'mīr serta para khatib. Tulisan ini menunjukkan bahwa karakteristik khutbah Jum'at di Masjid tersebut tercermin dalam keragaman khatibnya, baik dari sisi latar belakang pendidikan, bidang ilmu, afiliasi organisasi maupun profesi. Tulisan ini menemukan bahwa konten fiqh mu'āmalah belum menjadi perhatian para khatib. Temuan ini dibuktikan dengan tidak ditemukannya tema khutbah tentang fiqh mu'āmalah (mu'āmalah madiyah). Topik yang muncul dalam khutbah Jum`at berkenaan dengan prinsip-prinsip etik ekonomi dan bisnis Islam yang terkait dengan mu'āmalah adabiyah. Konten fiqh mu'āmalah yang sangat terbatas dalam khutbah Jum'at di masjid tersebut sekaligus merefleksikan rendahnya intensitas dialektika masjid sebagai ritual space dengan pasar sebagai economic space. Khutbah Jum'at di masjid ini masih kurang memberi perhatian lebih spesifik pada jama'ah pedagang pasar Johar sebagai segmen pentingnya.

Kata Kunci: fiqh mu'ämalah; khutbah Jum 'at; ritual space; economic space 
Musahadi

\section{Introduction}

In an article, Ekomadyo proposes a thesis that Islam should not be distant from social reality, including socio-economic realities that determine city life and solve urban problems. The socio-spatial relationship between mosques and markets can be an essential indicator of how strong Islam's influence is in urban development. A paradigm shift is needed in conveying Islamic values, namely from normative-symbolic to ideological-practical. ${ }^{1}$

The delivery of Islamic values, including through sermons, cannot stop at norms and symbols. However, it must contribute to building the idea of a better life, namely starting by looking at society's realities first and then looking for the appropriate norms. Not done in reverse, apply certain norms directly to human existence. Mapping reality is essential so that the Islamic idea of controlling religion in urban development can be accepted and implemented effectively by the community. ${ }^{2}$ This thesis needs to be seen factually through empirical observations on the practice of transforming Islamic values in mosques.

The mosque as a ritual space in this paper is associated with the market as a communal space (read: economical space) based on the concept of relations in the Javanese view, according to Depari and Setiadi, which is divided into four parts. ${ }^{3}$ First, the relationship between humans and God, which is manifested in the sacred space. Second, the relationship between humans and nature is manifested in open space. Third, the relationship between humans and the surrounding community is displayed in the communal area, and the fourth is the human-personal relationship embodied in the private space. In Islam, a mosque represents a sacred space that is spiritual, namely a place to build a relationship between humans and God through ritual activities. Simultaneously, a market is a profane communal space to make human relations with society through socioeconomic activities. The relationship between the two areas, namely between the mosque and the market, is fascinating.

${ }^{1}$ Agus S. Ekomadyo, 'Kajian Relasi Sosio-Spasial antara Masjid dan Pasar: Kajian atas Kontribusi Islam dalam Urbanitas Kontemporer', in Prosiding Seminar Nasional Arsitektur Islam 2 UMS: Kontribusi Arsitektur Islam dalam Mengatasi Permasalahan Perkotaan (Surakarta: PT. Rudi Persada Nusantara, 2012), 94.

${ }^{2}$ Ekomadyo, 94.

${ }^{3}$ Catharina Dwi Astuti Depari and Amos Setiadi, 'Makna Ruang Kampung Kauman Yogyakarta dan Semarang Berdasar Konsep Relasi dalam Pandangan Jawa', Tata Loka 16, no. 3 (2014): 135-36. 
Meanwhile, the mosque is still the object of criticism, especially by the internal Muslims themselves. The complaint is aimed at many aspects, from the call to prayer, the question of the imam, cleanliness, management, the development of the ritual element to his social role. One of the fundamental criticisms that are still loudly heard is regarding the imbalance of the mosque part, which is too heavy on the role of ritual and neglects its social function. Many mosques in this country only provide ritual services to their people and have little to say of not providing any social services to their congregation. The role of mosque rituals that should be brought closer and even placed as an instrument of community development and solving congregational problems is often presented in a formula that does not seem to be related to the "world" of the congregation.

One example of par excellence, in this case, is the Friday sermon ritual. This ritual has open and strategic access to enter the "world" of the congregation, understand its problems, detail its dynamics, and at the same time provide a clear and practical guideline for the community to deal with these problems within the framework of religion.

Many mosques have their sermon materials developed in the construction of the "world" of the preachers themselves and do not have a functional connection with the "world" of the congregation. The implication is that Friday sermons lose their role and function as an effective instrument for community development and solving society's actual problems. The content of Friday sermons is more dominated by directives for increasing ritual worship towards the formation of ritual diversions rather than discussing social issues and directions towards the construction of social transitions. ${ }^{4}$

In an article entitled Mosques and a Declining Civilization, Abdalla makes a sharp criticism of the role of mosques and Friday sermons in mosques, not only in Indonesia but also in mosques in the West. According to him, mosques are generally unable to present themselves as places that can be relied on by people to add religious insights intelligently. On the other hand, the mosque is a place to treat "scholarship" or mediocrity. It's no secret; in mosques, sometimes people are filled with demagogy, lectures full of cliches, repetition of boring

${ }^{4}$ A review of the tendency to prioritize ritual piety rather than social piety can be seen in the writing of Nadirsyah Hosen, 'Kesalehan Ritual dan Kesalehan Sosial', 2016, https://islam.nu.or.id/post/read/71189/kesalehan-ritual-dankesalehan-sosial. 
Musahadi

material, sometimes even insults that foster hatred. Abdalla assessed that when compared to sermons in American churches broadcast on TV (known as "televangelism"), it seems that the quality of their addresses, in general, is much better than the quality of sermons in mosques in Indonesia. Their rhetoric is even more intriguing. ${ }^{5}$ Even though it is very sharp and feels striking, this criticism seems very important for studying.

Many studies in Europe confirm this conclusion. Gurselin, through a series of interviews, also found several problems. Among them, the most important ones are: educated and devout Muslims in the Netherlands generally view that many Imams don't care about their sermons and their sermons are not relevant to the interests of the European younger generation. This is related to the next problem, namely the lack of language skills and knowledge of local culture, considering that Imams and preachers are usually imported from the mosque community's country of origin. ${ }^{6}$ According to Aandewiel, this problem is a factor that causes many young people not to pay attention to the sermon.7 In line with Gurselin, Lang (2004) also noted that the things most neglected in the discourse are the younger generation's needs. Islamic centers experience a bias in the orientation of the sermon, namely serving the needs of adults and children and ignoring young people's needs. ${ }^{8}$

However, it does not mean that all studies on sermons give negative conclusions. There is also a study of sermons from a more positive perspective. Hashem's study in Southern California is an example of this. Hashem questions two things, first how the ummah is projected in the sermon and how the address's nature is related to civil society. In conclusion, the collected material shows that the ummah concept is involved in three parameters: the potential role of the ummah, the obligation to help society, and the importance of unity in the social division of the ummah. According to this study, sermons are closely

5 Ulil Abshar Abdalla, 'Masjid dan Peradaban yang Merosot', 2006, https://islamlib.com/politik/dunia-islam/masjid-dan-peradaban-yang-mero sot/.

${ }^{6}$ Omer Faruk Gurlesin, 'Major Socio-Political Factors That Impact on the Changing Role, Perception and Image of Imams among Dutch-Turkish Muslims', Journal Education Science 9, no. 3 (2019).

${ }^{7}$ Jurjen Aandewiel, 'The Importance of Dakwah Facing the Challenges of Islam in the Netherlands' (Jakarta: The Jakarta International Islamic Conference (JAIIC), 2016).

8 Jeffry Lang, Losing My Religion: A Call For Help (Beltsville: Amana Publications, 2004). 
related to civil discourse. Although the sermon's focus gives priority to the Muslim community in the United States, its message of improving social realities extends to larger societies outside Muslim circles. ${ }^{9}$

Musahadi's study also shows positive conclusions. The mosque plays a significant role as a center of excellence in strengthening social harmony, political literacy, and social awareness. As a tangible manifestation of Islam, the orientation of mosques with their sermons balanced between religion and social functions can gradually erase the global perception of mosques that are often described as the birthplace of fundamentalism, extremism, and terrorism. ${ }^{10}$

After an extended period, Abdalla and other researchers criticized the mosque, especially regarding the sermon's content and packaging. It is interesting to see today the portrait of the Friday sermon. Do the Friday sermons in mosques today still show the same picture as indicated by them or show a different view. Is the Friday sermon content still suffering from the disease "irrelevance" to the needs of the congregation? Of course, so that data and analysis can be presented in a more focused manner, this paper limits itself to the one most representative mosque in the city of Semarang, namely the Great Mosque of Kauman Semarang.

The biggest congregation of this mosque are traders of Pasar Johar or traders who are active around the Kauman area of Semarang. An interesting question is how far the Friday sermons in the mosque are related to the needs of the majority who work as traders? The extent to which the Friday sermon content contains fiqh mu'āmalah must be practical knowledge in their daily economic transactions in the market and how the debate between the mosque as a ritual space and the market as an economic area occurs.

This study's primary data were obtained from the Friday sermon documents during 2015, starting from January 1 to December 31 2015, namely 51 recordings of Friday sermons in the form of MP3s stored in the ta'mir (mosque administrators) Office of the Great Kauman Mosque in Semarang what took the 2015 data considering that the last year Johar Market was functioning

\footnotetext{
${ }^{9}$ Mazen Hashem, 'The Ummah in the Khutba: A Religious Sermon or a Civil Discourse?', Muslim of Minority Affairs 30, no. 1 (2010).

10 Musahadi, 'The Role of Mosque and Khutba in Socio-Economic Development of Indonesia: Lessons from Kauman Mosque in Central Java', Global Journal Al Thaqafah 8, no. 2 (2018): 55-66.
} 
Musahadi

normally, considering that February 27, 2016, Pasar Johar caught fire and was subsequently relocated to another place. ${ }^{11}$ Also, to provide a deeper picture of the matter, interviews were conducted with the Foundation and Management of the Great Mosque of Kauman Semarang. To complete the data, I also worked interviews with the preachers.

\section{Mosque and Market: Two Pillars of Social Institutions}

Planologically, one of the characteristics of urban planning design in the Islamic world is the placing of mosques and markets in a two-in-one position. ${ }^{12}$ There is even a rather simplistic expression that "where there is a market, there is a mosque, where there is a mosque there is a market". There are valid historical references to this. Many books of hadith and Sirrah Nabawiyah record that when he moved to Medina and built a new social order in the new city, Muhammad saw the first social institution made is a mosque and a market.13

Perhaps this is what dispatched urban planning experts in the Islamic world to place these two institutions in one planological unity. Mosques and markets agree on organic function in expressing the achievement of ritual success and social transition in a balanced manner. Even today, this planological character is still ubiquitous in various Islamic cities. When a person makes a pilgrimage to the Prophet's Mosque in Medina or even the Grand Mosque in Mecca, he will quickly find multiple market activities, both traditional and modern, scattered around him.

In Indonesia, where the majority of the population is Muslim, they can quickly encounter this phenomenon. The building of the Great Mosque of Kauman Semarang, for example, is located adjacent to Pasar Johar, the trading center of Semarang City for hundreds of years. Even in the modern era when

11 'Kompleks Pasar Johar Semarang Kembali Terbakar', n.d., https://regional. kompas.com/read/2016/02/27/22072531/Kompleks.Pasar.Johar.Semarang.K embali.Terbakar.

${ }^{12}$ Wawan Hernawan and Ading Kusdiana, Biografi Sunan Gunung Djati, Sang Penata Agama di Tanah Sunda (Bandung: LP2M UIN Sunan Gunung Djati, 2020), 191.

${ }^{13}$ Patricia Sloane White, Corporate Islam: Modern Workplace (Cambridge: Cambridge University Press, 2017), 29-30; The first market built by the Prophet was Sūq al-Anșār sometime after the Hijrah. Suwandi, Muhammad Hakimi Mohd Shafiai, and Wan Nasyrudin Wan Abdullah, 'Pasar Islam (Kajian Alqur'an dan Sunnah Rasulullah SAW)', Al-Risalah: Farum Kajian Hukum dan Sosial Kemasyarakatan 16, no. 1 (2016): 134-35. 
modern shopping centers (malls and supermarkets) have sprung up in various corners of the city, Pasar Johar, adjacent to the Kauman Mosque, remains a vital traditional trading center for the people of Semarang City.

More than that, these two social institutions in the form of a mosque and a market have shaped the characteristics of the people living in the area, which are culturally called Kampung Kauman. Because it is supported by two social institutions, namely the mosque and the market, the Kauman community generally has a powerful religious bond as a community of santri because they become the primary support and inheritor of the traditions and rituals centered in the mosque. They are also generally traders, a very open profession to those who live close to markets. In short, the Kauman community, in general, are traders who are santri or santri who are traders. They are the primary support for the rituals held at the Kauman Mosque, including the implementation of Friday prayers.

Friday sermon is a practice of communicating, or more precisely, communication of da'wah. In communication, knowing and understanding the audience is one of the keys to successful communication. Optimizing communication requires not only knowledge of who the audience is but more than that of what their needs are. ${ }^{14}$ From a communication perspective, the preacher, as the deliverer of the sermon, is a communicator. If a preacher wants to be a good communicator, then he must have good thoughts (good sense), good morals (good moral), and good intentions (goodwill). ${ }^{15}$ Any effective communicator must have an ethos, including credibility, attractiveness, and expertise. Expertise means the communicant's impression of the communicator's expertise about the topic being discussed. The preacher who is trusted by his congregation will communicate effectively. Meanwhile, those who do not have credibility will ignore the congregation's communication. The

14 'Understand Your Audience | IEEE PCS', accessed 20 March 2016, https://procomm.ieee.org/communication-resources-for-engineers/audiencepurpose-and-context/understand-your-audience/; Debbie Devy in her writing entitled "Audience Analysis as Part of a Strategic Communication Framework" puts audience identification and assessment as the 3rd important step for successful communication. 'Audience Analysis as Part of a Strategic Communication Framework - IEEE Professional Communication Society', accessed 20 March 2016, https://procomm.ieee.org/audience-analysis-as-partof-a-strategic-communication-framework/.

${ }^{15}$ Jalaluddin Rahmat, Psikologi Komunikasi (Bandung: Remaja Rosda Karya, 1996), 225. 
Musahadi

community sees a khatib as an expert if he shows mastery of the material of his sermon and demonstrates his communication skills. De Vito concluded that "there is no communication situation where credibility has no influence."16

In line with this theory and logic, it is not an exaggeration to say that the effectiveness of Friday sermons is primarily determined by the preacher's ability and success in understanding and identifying the congregation, not only regarding their identity but also regarding their identity more than that regarding their needs. One of the needs of religious market traders is knowledge of fiqh mu'ämalah (knowledge of Islamic legal principles regarding economic activity). Yūsuf places this as one of the basic principles. It is obligatory for anyone who has a livelihood in the market to know the market's Islamic rules, namely about halal and haram, permissible and not, and which one is appropriate or violates the shari' $a$ for trading transactions in the market. ${ }^{17}$

\section{Overview of the Great Mosque of Kauman Semarang}

The Great Mosque of Semarang is the largest and oldest mosque in the city of Semarang, which is a cultural heritage. This mosque is one of the historical buildings closely related to the history of the formation of Semarang's town. Agus Fathuddin Yusuf mentioned that this mosque was initially founded by one of the Walisongo, who is known as the pioneer of Islam's spread in this area who was also the foundation stone for the founding of the city of Semarang. ${ }^{18}$

There is no single historical source that can conclusively explain when the Great Mosque of Kauman Semarang was founded. However, through a cultural approach, we can estimate the history of this mosque. Traditionally, Muslim communities have always constructed a mosque as their top priority when occupying an area. This can be used as a clue to identify when the mosque was founded. ${ }^{19}$

16 Josep A. Devito, Komunikasi Antarmanusia (Jakarta: Profesional Books, 1997), 459.

${ }_{17}$ Yūsuf Ibrāhīm Yūsuf, 'Al-Sūq fỉ Zill al-Islām: Shakluhā wa Dawābiṭ Wujūdihā', in Hawliyyah Kulliyyah al-Sharī'ah wa Al-Dirāsāt Al-Islāmiyyah (Qatar: Al-Jāmi'ah al-Qatar, 1988), 517-19.

${ }^{18}$ Agus Fathuddin Yusuf, Melacak Banda Masjid yang Hilang (Semarang: Aneka Ilmu, 2000), 2.

${ }^{19}$ Tim Peneliti MAJT, Sejarah Penulisan Masjid Kauman Semarang dan Masjid Agung Jawa Tengah (Semarang: BP MAJT, 2007), 197. 
In the fiqh doctrine, if a Muslim community in an area has reached a certain number $\left(60,40\right.$, or 21 men, for example), ${ }^{20}$ they must hold Friday prayers held in mosques. Therefore, establishing a mosque is a must for the newly formed Muslim community. Based on this fiqh doctrine, it seems inevitable that the Great Kauman Semarang Mosque, in a substantive sense, was founded at the end of the 15th century AD. The mosque's construction will certainly not be long after the presence of Pandan Arang in the Pulau Tirang area, which was later named Semarang.

The Great Mosque of Semarang was built by Sunan Pandan Arang, a Mawlā from Arabia whose original name was Mawlānā Ibn 'Abd al-Salām. At first, he got an assignment from Sunan Kalijaga to spread Islam in the western area of the Demak sultanate, namely Tirang Island, which was later called Semarang. Due to his significant influence in society, Sunan Pandan Arang was appointed as the first duke of Semarang. Since then, Sunan Pandan Arang is commonly called Adipati Pandan Arang I. This Duke has made the mosque he built a place of worship and teaching religion and government activities. This incident occurred in $1575 \mathrm{AD} .^{21}$

For the first time, this mosque was built in the Mugas area (now in the South Semarang area), then experienced several transfers, namely in Bubakan and finally in the Kauman area facing the Johar Market area. The Kauman Semarang area then developed a distinctive segment of cultural life, different from the Kauman area in other cities. Depari and Setiadi give a unique characteristic that Kampung Kauman Semarang is more determined by the magnitude of the influence of trading activities around the village. ${ }^{22}$

The Kauman Semarang community currently faces severe challenges in maintaining its identity as a santri community. In the past, Kauman was known as a storehouse of religious knowledge, especially the Koran's ability, which was

${ }^{20}$ In the Shāfi'ī School it is stated that the minimum number of Friday prayer congregants is 40 people, Taqī al-Dīn ibn Abī Bakr, Kifāyah Al-Akhyār (Surabaya: Al-Hidayah, n.d.), 145-47; The discussion about the difference in the minimum number of Friday Prayers, see Erman, 'Rekonstruksi Ketentuan Shalat Jum'at', Kutubkhanah Jurnal Penelitian Sosial Keagamaan 14, no. 1 (2011).

${ }^{21}$ Badan Kesejahteraan Masjid, Selayang Pandang Masjid Besar Semarang (Semarang, 1988), 4.

${ }^{22}$ Depari and Setiadi, 'Makna Ruang Kampung Kauman Yogyakarta dan Semarang Berdasar Konsep Relasi dalam Pandangan Jawa', 133. 
Musahadi

the goal of the Koran for the people of Semarang and its surroundings. The simple expression: "If you want to recite the Koran, memorize and master the Koran, come to Kauman!". However, now the situation has changed. The number of people living in Kauman is decreasing because the houses used to live in are now being sold not for housing but for doing business.

After the death of the Kiai who led the Islamic boarding schools (tahfiz alqur'ān) around Kauman, such as Kiai 'Abdullāh' Umar al-Hāfiz and Kiai Turmudhī al-Hāfiz, there was no successor generation with equal reputation. Kauman is no longer a center of religious knowledge where students from all over the city come to recite the Koran. Especially after the emergence of Kiai and ustādh (religious teachers) in various areas in Semarang, Kauman was no longer a center for learning the Koran.

\section{Friday Sermons and the Sociology of Fiqh of Worship}

The jurists agree that sermons are a valid prerequisite for Friday prayers. ${ }^{23}$ Some scholars argue, the number of raka'ät (the number of kneeling in prayer) for Friday prayers is condensed into two cycles because of the sermon. ${ }^{24}$ Its implementation is not just to fulfill the criteria so that Friday prayers are considered valid. More than that, sermons are designed to deliver compelling messages for the people's progress and benefit according to their respective contexts and characteristics.

The characteristics of Friday sermons at the Great Mosque of Kauman Semarang can be read and traced from the preacher's very diverse parts. This diversity of preachers reflects the mosque manager's policy to accommodate the large variety of ustādh and Kiai in Semarang and show a good strategy for bringing the sermon theme closer to the array of publicity issues that arise in everyday life. This diversity has positive implications in enriching the discourse and knowledge of the congregation.

In the sermon, the preachers set the stage by bringing several topics to the surface and then working to build bridges between them through various tools and strategies, especially intertextuality. It aims to contextualize Islamic texts

23 Husam Fahid Ibn Sa'īd, Ahkām Salāt al-Jumū'ah fì al-Fiqh al-Islām (Palestina: Jāmi'ah al-Najāh al-Wațaniyyah, 2015), 146-47.

${ }^{24}$ Wahbah Al-Zuhaylī, Al-Fiqh àl-Islāmī wa Adillatuh, 2nd ed. (Damaskus: Dār al-Fikr al-'Arabī, 1985), vols II; 394. 
such as Koran and Hadith into everyday matters and at the same time offer a platform to deal with everyday problems taking these religious texts into account. In this regard, the preachers act as cultural brokers. To achieve this goal, preachers can use intertextuality to reflect the sermon discourse's liminal status as a citizenship discourse driven by religion. 25

Their numbers, professional backgrounds, and disciplines can see the diversity of the mosque's preachers. In the 2015 Khatib schedule, there were 49 names of preachers from 51 Friday (2 January 2015 to 25 December 2015). Its means that almost all preachers only have the opportunity to preach at the mosque once a year. There are only two people who have a schedule of 2 sermons, namely Habib Ja'far Shodiq Al-Musawwa and KH. Muchammad Yashluch AG.

The khatib of this mosque came from the pesantren (Islamic boarding school), Kiai, the habä'ib (descendants of the Prophet), universities, professionals, socio-religious organizations, bureaucrats, and even hospital directors. In terms of educational backgrounds, they are also very diverse. Many of them are alumni of Islamic Religious Colleges, such as Institut Agama Islam Negeri (IAIN) or Universitas Islam Negeri (UIN), then completed their doctoral education at home or public universities abroad. Still, many of them are alumni of Islamic boarding schools both from within and outside the country.

Some of them have not received higher education in the Islamic religious discipline but general sciences, such as education, economics, or medicine. Those with a higher education background in Islamic religion also have concentrations in various fields, from tarbiyah, da'wah, fiqh, ușül al-dīn, tasāwuf, to Islamic philosophy. That is why the spectrum of themes, content, and perspectives of Friday sermons at the Great Mosque of Kauman Semarang is also vast and varied in line with the preacher's characteristics.

This phenomenon shows the difference with the da'wah phenomenon in Malaysia. In an article entitled Voices of Islamic Authorities: Friday Sermons in Malaysian Mosques. Mohd Al Adib Samuri \& Peter Hopkins concluded that government control and religious authorities over mosques in Malaysia are

${ }^{25}$ Emad S. Awad, 'Intertextuality in Friday Khutba', Journal of Islamic Studies and Culture 5, no. 1 (2017): 59-75. 
Musahadi

enormous.26 The government controls several aspects, including mosque administration, the appointment of mosque imams, and the compilation of sermon texts.

In terms of managing Friday sermons, ta'mïr includes several important rules related to Friday sermons at the Kauman Grand Mosque in Semarang on the schedule of sermons sent to each preacher. These rules, first, the sermon is carried out according to the terms and conditions of the sermon of the al-Shāfi'i school. Second, the preacher is present at least 30 minutes before prayer time. The Khatib who was unable to attend informed the ta'mir three days earlier. Third, before carrying out the sermon, the preacher occupies the transit room next to the mihrāb (pulpit) and wears the robe that has been provided.

The fourth rule, sermon duration, is 20 minutes with a breakdown of 15 minutes for the first sermon and 5 minutes for the second sermon. Ta'mīr provides a marker lamp above the pulpit as a reminder when the sermon is past the allotted time. Fifth, the sermon material is related to actual problems in society. Sixth, the preacher is expected to use text or notes to serve as an archive. Seventh, preachers who drive cars are provided with a special parking space north of the gate to make it easier for them to carry out their duties.

This strict regulation is understandable, considering that Friday sermons in Islamic teachings are an oral discourse with an orderly structure of discourse. This is because the sermon is included in the order of the main rituals of Friday worship so that it is included in the sacra area. Sacred and formal situations encourage the preacher to use formal and standard language to deliver the sermon. Besides, the rules, pillars, and requirements of the Friday sermon and their order strictly limit the situation and form a specific, standardized, and precise structure. ${ }^{27}$ If the charges and systems are not followed correctly, the ritual will be considered invalid. ${ }^{28}$

${ }^{26}$ Mohd Al Adib Samuri and Peter Hopkins, 'Voices of Islamic Authorities: Friday Khutba in Malaysian Mosques.', Journal Islam and Christian-Muslim Relations 28, no. 1 (2017): 47-67.

${ }^{27}$ Multazim AA, 'Status Hukum Tertib dalam Rukun Khutbah Jum'at (Telaah Kritis Fiqh Klasik)', Al-'Adalah: Jurnal Syariah dan Hukum Islam 4, no. 1 (2019): 60-73.

${ }^{28}$ Kundharu Saddhono et al., 'The Structure of Friday Sermon in Indonesia: A Socio Pragmatic Studies', in Proceedings of International Prasasti III: Current Research in Linguistics (Surakarta: UNS, 2016), 425. 
Fiqh Mu'ämalah Content ...

\section{Measuring the portion of Fiqh mu'ämalah in Friday Sermons}

According to Syafe'i, fiqh mu'ämalah is divided into two, namely mu'ämalah adabiyah and mu'ämalah mādiyah. ${ }^{29}$ Mu'ämalah adabiyah includes the principles of consent, mutual acceptance, no coercion from either party, rights and obligations, honesty of merchants, fraud, falsification, and everything that comes from the human senses that has something to do with the circulation of property. Whereas mu'ämalah mädiyah covers comprehensive aspects as follows: 1) Buying and selling (al-bay' al-tijärah), 2) Pawning (al-rahn), 3) Guarantees/dependents (al-kafälah), 4) Transfer of debts (al-hiwālah), 5) Falling back and forth (al-tafjis), 6) Limits of action (al-hajr), 7) Companies or partnerships (al-shirkah), 8) Property and labour companies (al-mudārabah), 9) Land leasing (al-musāqah al-mukhābarah), 10) Wages (ujr al-amah), 11) Lawsuit (al-shuf'ah), 12) Contests (al-ji'älah), 13) Sharing of shared wealth (alqisāmah), 14 ) Giving (al-hibah), 15) Liberation (al-ibra), peace (al-șulh), 16) Sharing of agricultural products (al-musāqah), 17) Cooperation in plantations (al-muzāra'ah), 18) purchasing of goods through orders (salam/salaf), 19) The funder lends money to the customer/capital provider (al-qirad), 20) Loans goods (al-'āriyah), 21) Rent a lease (al-ijārah), 22) Safekeeping of goods (al-wadi'ah). There are also rules related to everyday economic transactions ( $a l-$ $\left.m u^{\prime} a s ̦ i r a h\right)$, such as bank interest issues, insurance, credit, and other problems. ${ }^{30}$

Referring to this theory, studies that have been carried out on the recording of 51 Friday sermons in 2015 show no single lecture theme in fiqh mu'ämalah related to the terms, harmony, validity and cancellation of the contract. However, it does not mean that content on the economy, business and commerce are not discussed.

Discussions on economics, business, and commerce's themes and content are related to Islamic economics' ethical principles and business-related to mu'âmalah adabiyah. Three sermons allude to this matter: the sermon on Friday, January 16, 2015, with the khatib KH. Mohammad Azim Wasi', Friday sermon on August 7 2015, with Dr H. Musahadi, M.Ag., and Friday sermon on December 4, 2015, with the preacher Drs. KH. Ahmad Anas, M.Ag.

${ }^{29}$ Syafe'i Rachmad, Fiqh Muamalah (Bandung: Pustaka Setia, 2001), 16; Dede Rosyada, Hukum Islam dan Pranata Sosial (Jakarta: RajaGrafindo Persada, 1996), 75.

${ }^{30}$ Rosyada, Hukum Islam dan Pranata Sosial, 75. 
Musahadi

KH. Mohammad Azim Wasi' took the theme of optimizing the management, role, and function of mosques. Kiai Azim in his sermon conveyed that the mosque was not only a place of prayer but also a center of Islamic culture, a center for the development of Islamic scholarship, a center for the development of Islamic brotherhood and unity. More than that, it is time for a mosque to carry out its function as a driving force for the community's economy. This function is considered necessary considering that many people's conditions are still apprehensive, as shown by statistical data that 30-40 million people in Indonesia are still below the poverty line.

Based on a comparative study of mosque management in Singapore, Kiai Azim recommends that mosques in Indonesia be managed in a modern and professional manner as mosques in Singapore. To achieve the prosperity of the mosque and its people must direct mosque management. Mosques must have programs to improve the community's economy. The management of mosque assets is carried out in an accountable manner. Mosque work programs are limited to worship and touch on the economic empowerment of the people and alleviate poverty. ${ }^{31}$

H. Musahadi delivered the second sermon. This sermon discusses the theme of the importance of developing and spreading love and affection as a form of respect for the holy month of Ramadan as a month full of grace. Quoting Surah Al-Mā'idah (5): 8, Musahadi invites Muslims always to be committed to spreading love, compassion and justice to anyone on earth, whether in religious, social, political and economic matters.

Musahadi underlined that this verse's crucial moral message is the need to implement the values of love and justice in social life, in the process of witnessing and litigation, and in economic arrangements. People who can spread love and compassion to anyone who lives on this earth will also get love and affection from the Most loving and compassionate, namely Allah. The heart has a broad meaning, in the sense of spreading compassion to all human beings on earth regardless of differences, both in terms of religion, belief, class, political parties, as well as differences in social and economic terms. ${ }^{32}$

${ }^{31}$ Extracted from the recorded Friday sermon of KH. Mohammad Azim Wasi' on January 16, 2015.

${ }^{32}$ Extracted from the recorded Friday sermon of Dr. H. Musahadi, M.Ag. August 7, 2015. 
The following sermon was delivered by K.H. Ahmad Anas, who mentioned mu'ämalah (economic) idioms, such as commerce, business, and the financial system. He started his sermon by quoting Surah Al-Sāff (61): 10-12. The verse explicitly mentions the economic idiom of al-tijärah (commerce), although this verse's big topic is not economics. There are two conditions for a triumphant Muslim. First, have faith in Allah and His apostles. Second, jihād in Allah's way with wealth and soul. These two things are likened to a trade transaction between a Muslim and Allah who will never lose.

Referring to the idioms of al-tijärah and al-amwāl (property) in verse, Kiai Anas began to discuss business and the economic system. That Muhammad PBUH carried out the company. He gave an example of a work ethic in doing business that Allah encouraged through his oral, "i'mal li dunyāka kaannaka ta'îsh zamānan wa 'mal li äkhiratika ka annaka tamüt ghadan". ${ }^{33}$ He motivated his people to work optimally to achieve world success with commerce and business as if to live forever. However, whatever business is carried out, everything must be based on a fighting spirit based on believing in Allah.

Why is there so little, not to say nothing, the content of sermons that pertain to mu'âmalah or fiqh al-iqtișādì (economics), even though it is well aware that the congregation of Friday prayers at the Great Kauman Mosque are mostly traders? The answer is: first, the sermon is very short in duration and is delivered at a critical time, namely a work break that stimulates sleepiness. The preacher must use it effectively and efficiently.

Kiai Anas emphasized that the economic system developed by the Holy Prophet was a trust-based financial system. As an entrepreneur, the Holy Prophet set a perfect example of this system in monetary transactions. Being honest in economic practice is included in the meaning of jihäd because the Koran affirms that jihād is with wealth and soul. Awareness of this is essential because it can encourage people to function their property socially. The eternal life of wealth is when it is delivered in the way of Allah. Jihād does not only mean

${ }^{33}$ Although it is very popular and is often referred to in various pulpits of sermons, the validity of this hadith is still being debated. Even al-Albāni explicitly included it in the list of false traditions. Nașīr al-Dīn Al-Albānī, Silsilah al-Ahādìth al-Da'îfah wa al-Mawḍ̄'ah (Riyāḍ: Maktabah al-Ma'ārif li al-Nashr wa al-Tawzī', n.d.), 63. 
Musahadi

war. Jihād in the present context is a seriousness to seek knowledge, a sincerity to hold power in a trustful manner and includes a gravity to do business. ${ }^{34}$

Discussion about fiqh takes a long time because it involves a practical field ('amalì), including terms, harmony, validity, and a legal act's cancellation. Problems like this in the discussion require more appropriate time and more intensive concentration. Simultaneously, sermons held in the middle of the day or during work breaks are deemed not entirely suitable for fiqh materials, including mu'āmalah. In the middle of a break from a busy day of work, this short time is more effectively used to discuss light but very fundamental themes, namely themes related to moral development and motivation to increase good behavior.

At the Great Kauman Mosque, sermons are limited to 20 minutes. This sermon is divided into two parts, namely the first sermon and the second sermon. Between the two sermons, a preacher must sit for a moment. Bilal accompanied him with recitation and prayers.

The first sermon is divided into three segments, namely muqaddimah (introduction to the speech), the content of the address and ikhtitām (closing the sermon). Muqaddimah contains greetings. The preacher sits for a moment (when the preacher sits, the call to prayer is pronounced by bilāl), then hamdalah, shahādahh, salawāt, taqwā advice, recitation of the Koran and sometimes added reading of hadith. This muqaddimah is conveyed entirely in Arabic.

After that, the preacher enters the sermon's content delivered in Indonesian or sometimes Javanese. In this content section, the preacher has the freedom to convey the theme and material of the sermon. He said various religious knowledge and advice. Next, enter the ikhtitām segment, which contains prayers and istighfär, which are conveyed in Arabic. After that, the preacher sits for a moment (sitting between two sermons). The bilāl recites the prayer for about 0.5 minute, after which the preacher stands up again to deliver the second sermon.

This second sermon is delivered in Arabic, which contains hamdalah, shahādah, prayer, taqwā advice, reading the Koran, sometimes adding hadith readings and ending with prayer. Some preachers add to the material of their

${ }^{34}$ Extracted from the recorded Friday sermon Drs. KH. Ahmad Anas, M.Ag. December 4, 2015. 
sermons in this second sermon. Some others give conclusions to the speech before closing the address with worship. The segments of the discourse and the duration of time required are as follows:

Table: The division of sermon segments and their duration

\begin{tabular}{|c|c|c|c|}
\hline Sermons & Part & Language & Duration \\
\hline \multirow[t]{3}{*}{ First } & $\begin{array}{l}\text { Muqaddimah (Opening) } \\
\text { Salam } \\
\text { Sitting when adhan is echoed by bilal } \\
\text { hamdalah, } \\
\text { Shahādah, } \\
\text { Salawāt, } \\
\text { Taqwā advice, } \\
\text { Koran reading /plus Hadīth }\end{array}$ & Arabic & $\pm 2,5$ minutes \\
\hline & $\begin{array}{l}\text { Contents } \\
\text { Taqwā advice } \\
\text { Targhīb wa tarhīb }\end{array}$ & $\begin{array}{l}\text { Indonesian, } \\
\text { some use } \\
\text { Javanese } \\
\end{array}$ & \pm 15 minutes \\
\hline & $\begin{array}{l}\text { Ikhtitām (Closing) } \\
\text { Pray } \\
\text { Istighfār }\end{array}$ & & $\begin{array}{l} \pm 0,25 \\
\text { minutes }\end{array}$ \\
\hline $\begin{array}{l}\text { Sit between } \\
\text { two sermons }\end{array}$ & The recitation of Șalawāt by Bilal & Arabic & \pm 0.5 minutes \\
\hline \multirow[t]{3}{*}{ Second } & $\begin{array}{l}\text { Muqaddimah (Opening) } \\
\text { hamdalah, } \\
\text { Shahādah, } \\
\text { Salawāt, } \\
\text { Taqwā advice, } \\
\text { Reading the Koran/plus Hadīth }\end{array}$ & Arabic & $\begin{array}{l} \pm 0,75 \\
\text { minutes }\end{array}$ \\
\hline & $\begin{array}{l}\text { Contents } \\
\text { In general, the preacher does not deliver } \\
\text { material in the second sermon. Only a } \\
\text { few preachers add the content of the } \\
\text { sermon to the second sermon with a } \\
\text { conclusion. }\end{array}$ & $\begin{array}{l}\text { Indonesian, } \\
\text { some use } \\
\text { Javanese }\end{array}$ & $\pm 0,5$ minutes \\
\hline & $\begin{array}{l}\text { Ikhtitām (Closing) } \\
\text { Closing Pray }\end{array}$ & Arabic & $\pm 0,5$ minutes \\
\hline \multicolumn{3}{|c|}{ Total Time } & \pm 20 minutes \\
\hline
\end{tabular}

The table above shows that the sermon's total time is 20 minutes, while the time available for delivering the sermon material is only around 15 minutes. This short time is certainly not free time to convey heavy, complicated themes. 
Musahadi

Moreover, this time is a time for resting work and a relaxing time for the congregation to be sleepy.

Based on this illustration, it seems evident that giving sermons is not a simple skill. It is related to rhetorical proficiency, namely the knowledge of capturing the human soul through words. ${ }^{35}$ Through rhetoric, a preacher will have the ability to choose a topic, master subject development techniques, open and close sermon techniques and other related techniques.

The preacher, in this case, is required to be competent in reading the audience's situation and choosing light but substantive themes and sermon material. At the Kauman Mosque, generally, the preacher made a choice on moral building and motivation for a better life behavior. However, it does not mean that fiqh mu'ämalah themes and content are not attractive or cannot be chosen as the sermon's theme and scope. If the packaging still pays attention to time efficiency and wisely judges the audience's atmosphere, fiqh mu'âmalah themes and content are still exciting and can be a good choice.

Kiai Hanif Ismail, Chairperson of ta'mīr, explained that the dominance of moral development's theme does not mean that it is entirely independent of fiqh mu'âmalah because ethical issues underlie one's behavior, including in the economic behavior of congregations in financial transactions. This aspect of monotheism and ethics will impact and will significantly color one's behavior in observed behavior. Faith in religious teachings and adherence to Islamic ethical principles such as honesty, discipline, patience, politeness, love and compassion, and tenacity will undoubtedly significantly impact the congregation's business behavior.

Kiai Hanif's statement is logical. However, it is still hypothetical and needs to be tested for its validity on the traders' economic practice in Pasar Johar. This test is essential, considering that part of the people's memory about Pasar Johar's financial transactions is about "bombing prices". They are used to offering exorbitant prices for their merchandise, which can be up to three hundred per cent above the actual price. As a result, buyers do not dare to bid too low because if they bid too low, they are seen as cynical and sometimes scolded, while if they bid just slightly below the price offered by the trader, the

${ }^{35}$ Jalaluddin Rahmat, Retorika Modern: Pendekatan Praktis (Bandung: Remaja Rosda Karya, 2001), 1-6. 
fall will be too expensive-way above the actual price. The disparity between beliefs and ethical knowledge regarding economic transactions and the practice of financial transactions is still a challenge in this regard.

This kind of economic transaction model is undoubtedly not Syariah because buyers will feel sorry for buying at a too high price. Especially for people outside Semarang who have never transacted at Pasar Johar. They will be easy targets because they do not understand Pasar Johar traders' trading style in general. Even so, there are still many Pasar Johar traders who carry out transactions somewhat and transact in an Islamic manner, such as holding the principles of mutual willingness, honesty, no cheating, and wrongdoing other parties.

Another thing that can explain the scarcity of fiqh mu'ämalah content in Friday sermons at the Kauman Mosque in Semarang is the availability of particular time for more intensive Islamic scientific studies outside the sermon, namely routine recitations programmed into ta'mir activities. In recitations like this, content that requires intensive study such as fiqh mu'ämalah and business ethics is more appropriate to be studied and explored, such as Sunday afternoon recitation, recitation after Fajr, recitation at 10 am, recitation after Maghrïb.

The following explanation is the preacher's lack of awareness regarding the importance of a need assessment for the congregation. The characteristics and needs of the audience or Friday congregation of the Great Mosque of Kauman Semarang, which in general are traders, do not enter into their thoughtstructure at all. The preachers interviewed in this study generally admitted that the congregation's profile, which is the majority of Pasar Johar traders and businessmen in the vicinity, did not have the opportunity to be considered important in determining the theme and material of the sermon. There is only one preacher, Drs. KH. Ahmad Anas, M.Ag. Explicitly states that choosing the sermon's theme and content always puts the audience's variable characteristics into consideration. The congregation of the Great Mosque of Kauman Semarang, the majority of the merchant community, is essential in compiling the material for their sermons.

For the Kauman Mosque in Semarang, according to his scientific discipline, Anas tries to choose a sermon theme related to Da'wah and Economics in the framework of achieving a balance between material well-being and spiritual 
Musahadi

well-being. Wealth should be placed as an instrument (wasīlah), not a goal (ghāyah). That is, wealth must be recognized as a means to lead to the perfection of life as a servant of Allah through strenuous efforts to achieve righteousness to Him.

The exciting thing is, the preacher who places the audience (market traders and entrepreneurs) as consideration for choosing the theme of the sermon related to mu'ämalah, economy, business and commerce is not a person who has the discipline of fiqh mu'āmalah or economics. Kiai Ahmad Anas is an alumnus of the IAIN Walisongo Islamic Da'wah Faculty undergraduate program and the same IAIN Da'wah master program. Thus, the preacher with the discipline of da'wah (Islamic communication) has more concern for the sermon's audience than others. More than that, those who have a background in sharīa (fiqh mu'ämalah) and economics do not necessarily place fiqh mu'ämalah and economics as the theme and content sermons.

Kiai Khammad Ma'sum put forward another explanation for the interview session. According to him, there are indeed business people who are preachers, but it is scarce. They are generally lecturers, officials and Kiai. Even though they have theoretical knowledge related to fiqh mu'āmalah and business jurisprudence, on average, they are not business people. This situation caused reluctance among the preachers to talk about fiqh mu'ämalah and business practices. "Ora dagang kokngajari dagang wong Kauman?" (Not a trader how to teach trading to the Kauman people).

The data presented above shows that the content of fiqh mu'ämalah is minimal to be found in Friday sermons at the Great Mosque of Kauman Semarang. Of course, this can be an essential point of attention for ta'mirs and khatibs to develop sermon designs in the future. The mosque has exceptional attention to its congregation's characteristics, which happens to be the majority of businessmen and traders.

The minimal content of fiqh mu'ämalah in Friday sermons at the Great Mosque of Kauman Semarang at the same time reflects the intensity of the mosque's dialectic as a ritual space with the market as an economic space. The limited awareness of the preachers about the importance of conducting a need assessment (mapping of needs) of the audience (congregation) of the Great 
Mosque of Kauman Semarang, where the majority of traders in Kauman and Pasar Johar, as recognized by the preachers, make this dialectic still very limited.

\section{Conclusion}

The socio-spatial relationship between the Kauman Mosque as a ritual space and Pasar Johar as an economic space shows that there has been a paradigm shift in the delivery of Islamic values, from normative-symbolic to ideological-practical. The delivery of Islamic values through Friday sermons does not stop at norms and symbols but has contributed to building ideas about a better life. Mosque resources also support this. The preacher of this mosque has various backgrounds, including Kiai, habā'ib, universities, religious organizations, professional organizations and the bureaucracy. This variety causes the spectrum of sermon themes, content, and perspectives to be comprehensive and varied.

However, Friday sermons at the Kauman Grand Mosque in Semarang paid little attention to its audience's largest segment, namely market traders. Fiqh mu'ämalah does not get adequate attention in sermons. During one year, the economy, business, and commerce issues were alluded to in just three sermons. This fact shows the preachers' limited awareness about the importance of conducting a need assessment for the congregation of the Great Mosque of Kauman Semarang, most of which are traders in the mosque and Johar market. It also reflects the low intensity of the mosque's dialectic as a ritual space with the market as an economic space.[a]

\section{BIBLIOGRAPHY}

AA, Multazim. 'Status Hukum Tertib dalam Rukun Khutbah Jum'at (Telaah Kritis Fiqih Klasik)'. Al-'Adalah: Jurnal Syariah dan Hukum Islam 4, no. 1 (2019).

Aandewiel, Jurjen. 'The Importance of Dakwah Facing the Challenges of Islam in the Netherlands'. Jakarta: The Jakarta International Islamic Conference (JAIIC), 2016.

Abdalla, Ulil Abshar. 'Masjid dan Peradaban yang Merosot', 2006. https://islamlib.com/politik/dunia-islam/masjid-dan-perada ban-yang-merosot/. 
Musahadi

Al-Albānī, Nașīr al-Dīn. Silsilah al-Ahādīth al-Da'îfah wa alMawdū'ah. Riyāḍ: Maktabah al-Ma'ārif li al-Nashr wa alTawzì', n.d.

'Audience Analysis as Part of a Strategic Communication Framework - IEEE Professional Communication Society'. Accessed 20 March 2016. https://procomm.ieee.org/audience -analysis-as-part-of-a-strategic-communication-framework/.

Awad, Emad S. 'Intertextuality in Friday Khutba'. Journal of Islamic Studies and Culture 5, no. 1 (2017).

Badan Kesejahteraan Masjid. Selayang Pandang Masjid Besar Semarang. Semarang, 1988.

Bakr, Taqī al-Dīn ibn Abī. Kifāyah al-Akhyār. Surabaya: Al-Hidayah, n.d.

Depari, Catharina Dwi Astuti, and Amos Setiadi. 'Makna Ruang Kampung Kauman Yogyakarta dan Semarang Berdasar Konsep Relasi dalam Pandangan Jawa'. Tata Loka 16, no. 3 (2014).

Devito, Josep A. Komunikasi Antarmanusia. Jakarta: Profesional Books, 1997.

Ekomadyo, Agus S. 'Kajian Relasi Sosio-Spasial Antara Masjid dan Pasar: Kajian Atas Kontribusi Islam dalam Urbanitas Kontemporer'. In Prosiding Seminar Nasional Arsitektur Islam 2 UMS: Kontribusi Arsitektur Islam dalam Mengatasi Permasalahan Perkotaan. Surakarta: PT. Rudi Persada Nusantara, 2012.

Erman. 'Rekonstruksi Ketentuan Shalat Jum'at'. Kutubkhanah Jurnal Penelitian Sosial Keagamaan 14, no. 1 (2011).

Gurlesin, Omer Faruk. 'Major Socio-Political Factors That Impact on the Changing Role, Perception and Image of Imams among Dutch-Turkish Muslims'. Journal Education Science 9, no. 3 (2019).

Hashem, Mazen. 'The Ummah in the Khutba: A Religious Sermon or a Civil Discourse?' Muslim of Minority Affairs 30, no. 1 (2010).

Hernawan, Wawan, and Ading Kusdiana. Biografi Sunan Gunung Djati, Sang Penata Agama di Tanah Sunda. Bandung: LP2M UIN Sunan Gunung Djati, 2020.

Hosen, Nadirsyah. 'Kesalehan Ritual dan Kesalehan Sosial', 2016. 
Fiqh Mu'ämalah Content ...

https://islam.nu.or.id/post/read/71189/kesalehan-ritualdan-kesalehan-sosial.

'Kompleks Pasar Johar Semarang Kembali Terbakar', n.d. https:// regional.kompas.com/read/2016/02/27/22072531/Komple ks.Pasar.Johar.Semarang.Kembali.Terbakar.

Lang, Jeffry. Losing My Religion: A Call For Help. Beltsville: Amana Publications, 2004.

Musahadi. 'The Role of Mosque and Khutba in Socio-Economic Development of Indonesia: Lessons from Kauman Mosque in Central Java'. Global Journal Al Thaqafah 8, no. 2 (2018).

Rachmad, Syafe'i. Fiqih Muamalah. Bandung: Pustaka Setia, 2001.

Rahmat, Jalaluddin. Psikologi Komunikasi. Bandung: Remaja Rosda Karya, 1996.

-_—. Retorika Modern: Pendekatan Praktis. Bandung: Remaja Rosda Karya, 2001.

Rosyada, Dede. Hukum Islam dan Pranata Sosial. Jakarta: RajaGrafindo Persada, 1996.

Sa'īd, Ḥusam Fahid Ibn. Ahkām Salāt al-Jumū'ah fì al-Fiqh al-Islām. Palestina: Jāmi'ah al-Najāḥ al-Wațaniyyah, 2015.

Saddhono, Kundharu, Nugraheni Eko Wardani, Chafit Ulya, and Yusuf Muflikh Raharjo. 'The Structure of Friday Sermon in Indonesia: A Socio Pragmatic Studies'. In Proceedings of International Prasasti III: Current Research in Linguistics. Surakarta: UNS, 2016.

Samuri, Mohd Al Adib, and Peter Hopkins. 'Voices of Islamic Authorities: Friday Khutba in Malaysian Mosques.' Journal Islam and Christian-Muslim Relations 28, no. 1 (2017).

Suwandi, Muhammad Hakimi Mohd Shafiai, and Wan Nasyrudin Wan Abdullah. 'Pasar Islam (Kajian Alqur'an dan Sunnah Rasulullah SAW)'. Al-Risalah: Farum Kajian Hukum dan Sosial Kemasyarakatan 16, no. 1 (2016).

Tim Peneliti MAJT. Sejarah Penulisan Masjid Kauman Semarang dan Masjid Agung Jawa Tengah. Semarang: BP MAJT, 2007.

'Understand Your Audience | IEEE PCS'. Accessed 20 March 2016. https://procomm.ieee.org/communication-resources-forengineers/audience-purpose-and-context/understand-your- 
Musahadi

audience/.

White, Patricia Sloane. Corporate Islam: Modern Workplace. Cambridge: Cambridge University Press, 2017.

Yusuf, Agus Fathuddin. Melacak Banda Masjid yang Hilang. Semarang: Aneka Ilmu, 2000.

Yūsuf, Yūsuf Ibrāhīm. 'Al-Sūq fĩ Zill al-Islām: Shakluhā wa Dawābit Wujūdihā'. In Hawliyyah Kuilliyyah al-Sharī'ah wa al-Dirāsāt alIslāmiyyah. Qatar: Al-Jāmi'ah al-Qatar, 1988.

Al-Zuhaylī, Wahbah. Al-Fiqh al-Islāmī wa Adillatuh. 2nd ed. Damaskus: Dār al-Fikr al-'Arabī, 1985. 